\title{
1. Global health law: defining the field
}

Brigit Toebes

\section{SETTING THE SCENE}

The topic of this Research Handbook is global health law, a field of international law that is steadily receiving increasing attention from scholars in law and governance. ${ }^{1}$ Due to ongoing globalization we are witnessing serious challenges in the health field, varying from the spread of disease across borders and an increase in non-communicable diseases, to the detrimental health effects of environmental pollution, climate change, and armed conflict. Global health law may potentially be an important tool to address these concerns.

We have invited key experts in the field to analyse a range of dimensions of global health law. We perceive their contributions to be manifestations of the definition and concepts adopted in the field, giving substance to the body of global health law in a multitude of ways. While some contributions explicitly engage with global health law as a field, others are indirectly linked to the overarching theme of this Handbook. This introductory chapter sets the stage for these contributions by raising some preliminary questions concerning the scope, nature, and normative foundations of global health law.

\section{SCOPE}

Global health law consists of a limited set of binding and non-binding instruments adopted in the framework of the World Health Organization (WHO), in an interaction with both hard and soft law standards recognized in other branches of international law, including human rights law,

1 E.g. Jennifer Prah Ruger, 'Normative Foundations of Global Health Law' (2008) 96 The Georgetown Law Journal 423, Lawrence O. Gostin, Global Health Law (Harvard University Press 2014), Michael Freeman, Sarah Hawkes and Belinda Bennett, Law and Global Health - current legal issues (Volume 16, Oxford University Press 2014), and Gian Luca Burci (ed.), Global Health Law (International Law Series, Volume 1, Edward Elgar Publishing 2016). 
international humanitarian law, international environmental law, international trade, property and investment law. ${ }^{2}$ In addition, Burci observes in his concluding chapter that there are many regional and sub-regional frameworks within which health-related standards have been adopted, including the European Union, Council of Europe, Pan American Health Organization, and West-African Health Organization. ${ }^{3}$ Given its highly fragmented nature, we are unable to definitively determine whether global health law deserves the label of an emerging or existing branch of international law.

The various chapters in this book affirm that there is a complex interaction between international health-related standards including inter alia the expression of health as a normative value in the context of these various branches of international law. We stress that the book is not exhaustive of all these interactions, and leaves many dimensions uncovered, including for example the protection of occupational health, the regulation of arms control, and the interaction between health and international migration. We further emphasize that our focus is on law, and 'global health law' more specifically, as one of the many tools employed in health governance. ${ }^{4}$ As Moon explains in her contribution to this volume, 'global health law is part of a larger global social and political process', and there are many other tools and mechanisms that actors may utilize to influence global governance processes. ${ }^{5}$

It is also important to observe that the standards that we perceive to form part of global health law are not always binding in nature. Rather, global health law consists of an intricate patchwork of hard and soft law standards. ${ }^{6}$ Burci, in his concluding chapter to this volume, elaborates on

2 Brigit Toebes, 'International Health Law: an emerging branch of public international law' (2015) 55(3) Indian Journal of International Law 299-328. See also Gostin (n 1) xii and 59.

3 As Burci explains in his concluding chapter, the Council of Europe's work on health matters includes the harmonization of specifications for medicinal substances and the Convention on the Elaboration of a European Pharmacopoeia and its protocols, the instruments in the field of human rights and biomedicine, and the recent convention on counterfeiting of medical products ('Medicrime Convention').

4 More on this see the contribution by Moon, section 1 .

5 Moon, section 2.

6 In conversation with Gian Luca Burci. Sandesh Sivakumaran makes a similar observation in relation to International Law of Disaster Relief, in 'Techniques in International Law-Making: Extrapolation, Analogy, Form and the Emergence of an International Law of Disaster Relief' (2017) 28(4) EJIL 1097-132. 


\section{Research handbook on global health law}

the nature and implications of this phenomenon. We take as a starting point that soft law standards may play a significant normative and regulatory role in global health law. Sekalala has argued that in the health field, soft law may even be more effective than hard law, and has illustrated this by demonstrating how soft law standards have been instrumental in the fight against malaria and tuberculosis. ${ }^{7}$ Several international law scholars have emphasized the importance of both hard and soft standards as tools for international legalization. ${ }^{8}$ According to Pauwelyn and colleagues, we are increasingly moving toward complex transnational societies of networks with the increasing involvement of new international actors on the international stage, engaging in new forms of collaboration. ${ }^{9}$ Soft law standards have been an influential tool to address these interactions and they play an important role in filling regulatory gaps. ${ }^{10}$

When it comes to soft law standards relevant to global health law, we see a wide range of standards that carry varying levels of authority and influence. Authoritative soft law standards include but are not limited to the WHO Code on the Marketing of Breast-Milk Substitutes, the Guidelines for implementation of the WHO Framework Convention on Tobacco Control, and the standards adopted by the WHO/FAO Codex Alimentarius Commission. ${ }^{11}$ While these standards were adopted with the consent of States, it appears that this is not a prerequisite for influence and authority. A clear example concerns the guidelines adopted within the framework of the International Council for Harmonization of Technical Requirements for the Pharmaceuticals for Human Use (ICH). As Seuba explains in his contribution to this Handbook, the $\mathrm{ICH}$ is an influential body and Member States and non-participating countries implement its guidelines. All in all, the drive towards soft law in the

7 Sharifah Sekalala, Soft Law and Global Health Problems (Cambridge University Press 2017).

8 Kenneth W. Abbott and Duncan Snidal, 'Hard and Soft Law in International Relations' (2000) 54(3) International Organization 3, 421-56, Joost Pauwelyn, Ramses A. Wessel and Jan Wouters, 'The Stagnation of International Law', October 2012 (Leuven Centre for Global Governance Studies, Working Paper No. 97).

9 Pauwelyn et al (n 8) 10.

10 See also Sekalala (n 7).

11 WHO Code on the Marketing of Breastmilk Substitutes, WHO 1981, Guidelines for implementation of the WHO Framework Convention on Tobacco Control, FCTC COP 2007, 2008, 2010 and 2012, and the standards adopted by the WHO/FAO Codex Alimentarius Commission, <http://www.fao.org/fao-whocodexalimentarius/en/>, accessed 2 February 2018. 
health field and development of standards should be followed with caution, and the nature and effect of these standards should be valued on a case-by-case basis.

\section{GLOBAL VERSUS INTERNATIONAL HEALTH LAW}

From a definitional perspective, the question arises whether we should use the term global instead of international health law. ${ }^{12}$ The more traditional term international health law is consistent with the terms used for other existing branches of international law, including international environmental law, international humanitarian law, and international trade law. ${ }^{13}$ So why opt for the term global health law?

As Moon explains in her contribution to this volume, in governance literature the term global health has increasingly come to displace the older international health. ${ }^{14}$ Given that the concept of health and its multiple determinants have become increasingly globalized, Moon and colleagues have argued for a broader conceptualization of global health as 'the health of the global population, with a focus on the dense relationships of interdependence across nations and sectors that have arisen with globalization'. ${ }^{15}$

Along similar lines, the term global health law potentially reflects the consequences of globalization in the health field, including the increasing role and power of multiple actors in global health governance. ${ }^{16}$ According to Prah Ruger, while international health law connotes a more traditional approach derived from rules governing relations among nation States, global health law is developing an international structure based on the world of a community. ${ }^{17}$ Hence, while in doubt, in this volume we use the term global instead of international health law.

By way of a disclaimer, we perceive the term global health mainly as a reflection of the globalized nature of health, however not necessarily as a normative concept encapsulating the legal nature and scope of global

\footnotetext{
12 Toebes (n 2).

13 Ibid.

14 Moon in this volume, 1.1.

15 J. Frenk, O. Gómez-Dantés, and S. Moon, 'From Sovereignty to Solidarity: A Renewed Concept of Global Health for an Era of Complex Interdependence' (2014) 383(9911) The Lancet 94-7.

16 Obijiofor Aginam, 'Mission (Im)possible? The WHO as a "Norm Entrepreneur" in Global Health Governance', in Michael Freeman, Sarah Hawkes and Belinda Bennet (eds.), (n 1), section 3.

17 Prah Ruger (n 1).
} 
health law as a whole. What we mean here is that many health standards still have an 'international' orientation as a result of their development and negotiation by States as well as their adoption within the framework of international organizations. Other standards however go beyond this international orientation and are thus more 'globally' oriented. This includes the above-mentioned soft law standards, or standards that have been adopted in non-governmental networks.

\section{NORMATIVE FOUNDATIONS}

There is widespread recognition that health is an important matter of international concern. The first step towards this affirmation came with the preamble to the 1946 Constitution of the World Health Organization. It states that 'the health of all peoples is fundamental to the attainment of peace and security and is dependent upon the fullest co-operation of individuals and States'. ${ }^{18}$

Over the past decades, several authors have discussed the normative foundations of global health, and more specifically global health law. Prah Ruger, in her authoritative work on global health law and governance, argues in favour of a theory of health justice, based on the theory that society's obligation to maintain and improve health is founded on the ethical principle of human flourishing or human capability. ${ }^{19}$ Along similar lines, Venkatapuram proposes the 'capability to be healthy' approach, an analytical and ethical framework that is grounded in the capability approaches developed by Amartya Sen and Martha Nussbaum. ${ }^{20}$ According to Venkatapuram, health capability recognizes every human being's moral entitlement to a capability to be healthy, an entitlement grounded in dignity and equal respect. ${ }^{21}$ In response to this entitlement, societies should focus on supporting the 'capabilities of individuals to conceive, pursue, and revise their life plans'. ${ }^{22}$ In the context of this approach, Venkatapuram builds a bridge to human rights

\footnotetext{
18 Constitution of the World Health Organization 1946.

19 Jennifer Prah Ruger, 'Ethics and Governance of Global Health Inequalities’ (2006) 60 J. Epidemiology \& Cmty Health 998; Prah Ruger (n 1), 430.

20 E.g. A. Sen, 'Elements of a Theory of Human Rights' (2004) 32(4) Philosophy \& Public Affairs 315 and M.C. Nussbaum, Creating Capabilities: The Human Development Approach (Cambridge University Press 2011).

21 Venkatapuram, Health Justice (Polity Press 2011) 19 and 113.

22 Venkatapuram (n 21) 115. See also Brigit Toebes, 'Review Article Health Justice by Sridhar Venkatapuram' (2012) 30(2) Netherlands Quarterly of Human Rights 245.
} 
law by recognizing a right to the capability to be healthy, which he perceives as a right to a cluster of diverse entitlements and rights. ${ }^{23}$

This begs the question: what is the role of human rights in global health law? Given their normative value, human rights standards have the potential to play an important role in giving expression to the normative foundations of global health law. ${ }^{24}$ By recognizing entitlements to health, privacy, physical integrity and other interests of individuals, they give further substance to concepts such as health equity, justice, and health capability. ${ }^{25}$ However, there is some confusion regarding the precise connection between global health law and human rights law, as is discussed by Tobin and Murphy in their respective chapters in this volume. More attention is paid to this matter in the next section, which discusses how human rights law interacts with global health law.

In relation to this, the question arises whether there are general principles of law playing a foundational role in global health law. ${ }^{26}$ As Kolb asserts, on the one hand, principles are general and flexible in nature, while on the other hand, they are legal and hold a core meaning. ${ }^{27}$ Principles can provide a dynamic interpretation of global health law while at the same time offering operational guidance in interpreting key topics and questions underlying the overall body of global health law.

Traditionally, general principles of law within the meaning of Article 38 of the Statute of the International Court of Justice were understood as referring to principles of domestic law that are common to all legal systems. ${ }^{28}$ Examples include the principles of good faith and estoppel. ${ }^{29}$ However, there is increasing recognition that Article 38(1)(c) also

23 Venkatapuram (n 21) 23.

24 Prah Ruger (n 1) 427.

25 Gostin (n 1) 12-as also referred to by Tobin in his contribution to this volume.

26 As suggested in conversation with several scholars, including Yutaka Tejima, Gian Luca Burci, André De Hoogh, and Panos Merkouris.

27 Robert Kolb, Advanced Introduction to International Humanitarian Law (Edward Elgar Publishing 2014) 75.

28 Article 38 Statute ICJ: principles 'recognized by civilized nations'. E.g. Hugh Thirlway, 'The Sources of International Law', in Malcolm D. Evans (ed.), International Law (2nd edn, Oxford University Press 2006) 115, 128. Also E.V. Koppe, 'The Principle of Ambituity and the Prohibition against Excessive Collateral Damage to the Environment during Armed Conflict' (2013) 82(1) Nordic Journal of International Law 53, 61. The term 'civilized' is considered to be outdated.

29 Malcolm Shaw, International Law (7th edn, Cambridge University Press 2017) 75-6. 
includes general principles of international law. ${ }^{30}$ Such principles do not have their origins in domestic law but often emerge from soft law and subsequently obtain binding force through their recognition in binding texts, customary law, and international courts and tribunals. Scholars assert that this trend reflects the increasing emancipation of international law from rudimentary to a more sophisticated legal order with multilateral treaties. ${ }^{31}$ We may thus make a very rough distinction between general principles that are grounded in domestic law and principles that originated internationally.

In their chapter on international environmental law, Mbengue and Waltman illustrate how general principles play a foundational role in international environmental law, including sustainable development, the precautionary principle, the principle of (inter and intra) generational equity, and the principle of preventative action. ${ }^{32}$ Along similar lines, Bellal, in her contribution to this volume, explains how the principles of military necessity, humanity, proportionality, distinction and precaution play a key role in international humanitarian law. ${ }^{33}$ While some of these principles have their origins in domestic law (e.g. the principle of distinction), several others have emerged in international law through soft law. ${ }^{34}$

Leaving aside the question of whether principles originate from domestic or international law, we should discuss which concepts can potentially feature as principles of global health law. ${ }^{35}$ Given that this discussion is extremely rudimentary and undeveloped, such identification at this stage is only a matter of speculation. To some extent, inspiration can be drawn from the above-mentioned fields of international humanitarian law and international environmental law, as well as other bodies of international law. Principles such as equity, solidarity and proportionality may emerge as foundational principles of global health law. ${ }^{36}$

30 Koppe (n 28) 61-2, referring also to Separate Opinion of Judge Cançado Trindade, in the Case Concerning Pulp Mills on the River Uruguay (Argentina $v$. Uruguay), ICJ Reports 2010, paras 26, 28, 29-47.

31 O. Spijkers, The United Nations, the Evolution of Global Values and International Law (Intersentia 2011).

32 See the chapter by Mbengue and Waltman in this volume.

33 See the chapter by Bellal in this volume.

34 As discussed in conversation with André De Hoogh.

35 As also discussed with Yutaka Tejima.

36 E.g. Rebecca Cook, 'Gender Equity in Global Health Law' (2014) III(1) Global Health Governance 13; Eduardo Arenas Catalan, Solidarity and the Right to Health in the Era of Healthcare Commercialisation (unpublished); R.St.J. 
Furthermore, in light of the discussion in the context of health justice, the concept of health capability discussed above may also emerge as a principle of global health law. ${ }^{37}$ Importantly, health capability takes a broad approach to health by integrating the biomedical model of health with the social determinants to health. Health capability further recognizes that a broad range of social arrangements contributes to the health of individuals. ${ }^{38}$ Taking Venkatapuram's health capability approach as a starting point facilitates the recognition of an entitlement to a cluster of rights which States and other actors are required to guarantee. These claims are thereby grounded in 'equal human dignity'. ${ }^{39}$ As such, there is a clear parallel to the field of human rights law, where the concept of human dignity plays a similar foundational role.

In domestic health law, a range of authoritative, more specific principles have been developed, including notions of autonomy, privacy, integrity and confidentiality, which primarily protect the individual from harm by others, in particular in healthcare settings. ${ }^{40}$ Furthermore, the so-called 'AAAQ' (availability, accessibility, acceptability and quality) serves as an indicator for the provision of health services and also finds recognition in several domestic legal settings. ${ }^{41}$ It should be noted that some of these notions are fairly specific and may not have the overarching nature of the more foundational principles suggested above. Alternatively, they may be seen as specific concepts clarifying the content of health-related obligations, serving the purpose of implementation and monitoring. ${ }^{42}$

Taking these more narrow principles as starting points in global health law may nonetheless give expression to an emerging polarity in global health law. We can draw an analogy here with international environmental law and international humanitarian law, where principles have generally developed within the context of two fundamental objectives that pull in opposite directions. In international environmental law, while

McDonald, 'Solidarity in the Practice and Discourse of Public International Law' (1996) 8(2) Pace International Law Review.

37 Prah Ruger (n 1), Venkatapuram (n 21).

38 Venkatapuram (n 21) 8 and 234-5.

39 Venkatapuram (n 21) 233.

40 Mette Hartlev, 'Patients' Rights', in B. Toebes et al (eds), Health and Human Rights in Europe (Intersentia 2012) 111.

41 E.g. Brigit Toebes and Maite San Giorgi, 'Dutch Realities: evaluating the Dutch health care reform from a human rights perspective', in B. Toebes et al (eds.), The Right to Health: A Multi-Country Study of Law, Policy and Practice (TMC Asser Press/Springer, 2014) 422, 431.

42 As expressed by Gian Luca Burci in conversation. 
States have sovereign rights over their natural resources, they must not cause damage to the environment. ${ }^{43}$ Similarly, in international humanitarian law, belligerent parties must balance the principle of humanity against military necessity. In global health law a similar tension seems to exist between the protection of the health of the public at large (to some extent reflected by the AAAQ) and the protection of a range of other (mainly individual) interests, including privacy, physical integrity, freedom of movement, but also individual health and social welfare protection. ${ }^{44}$ Although this idea is very rudimentary and in likelihood does not fully reflect the body of principles that may potentially develop under global health law, it merits further reflection and debate.

\section{WHO STANDARDS}

As previously outlined, global health law consists of a narrow body of legally binding and non-binding instruments adopted under the framework of the WHO, in an interaction with hard and soft law standards recognized in existing branches of international law. 45 To some extent, this Handbook's focus on the WHO as the main international standardsetter in the health field is somewhat limited and artificial. There are several other bodies that have adopted authoritative health-related standards. Important examples include the treaties adopted within the framework of the International Law Organization (ILO) and the UN Standard Minimum Rules for the Treatment of Prisoners. ${ }^{46}$

Chapter V of the WHO Constitution grants the World Health Assembly (WHA) considerable standard-setting powers, enabling the WHA to adopt treaties, regulations, and recommendations ${ }^{47}$ However, to date the WHA has made only marginal use of these competences. As will be discussed further below, it has adopted only one treaty, two regulations,

43 Philippe Sands, Principles of International Environmental Law (Cambridge University Press 2012) 190-1.

44 Benjamin Mason Meier, 'Advancing Health Rights in a Globalized World: Responding to Globalization through a Collective Human Right to Public Health' (2007) 35 Journal of Law, Medicine and Ethics 545; Brigit Toebes, 'Human Rights and Public Health: Towards a Balanced Relationship' (2015) 4(19) International Journal of Human Rights 488.

45 See also Gostin (n 1) 59-60.

46 International Labour Organization, <http://www.ilo.org/global/lang-en/ index.htm>, accessed 2 February 2018; Standard Minimum Rules for the Treatment of Prisoners, 1977.

47 Articles 19, 21 and 23 of the WHO Constitution. Aginam (n 16). 
and a range of non-binding recommendations. Compared to the extensive regime developed within the ILO, this outcome is disappointing. The Assembly's reticent attitude towards standard-setting has been discussed and widely criticized in the literature. ${ }^{48}$ Aginam observes that the WHO has yet to maximize its potentials as an effective and efficient "norm entrepreneur' in the global health architecture. ${ }^{49}$ Seuba, in his contribution to this volume, observes that the WHA has not adopted a single regulation in the pharmaceutical domain, an 'apparent neglect' that would 'seem to respond to a historical stance favouring recommendations and disliking hard-law tools'. 50 Yet limited as this regime may be, the standards adopted under the framework of the WHO are considered to form the core of global health law and thus are carefully considered in this Handbook.

Firstly, Article 19 of the WHO Constitution enables the WHA to adopt conventions or agreements (treaties) with respect to matters within the competence of the WHO. In 2003, the first treaty was adopted on the basis of this competence, i.e. the Framework Convention on Tobacco Control (FCTC). As Zhou and Liberman convey in their contribution to this work, the WHA called the treaty a 'groundbreaking step in advancing national, regional and international action and global cooperation to protect human health against the devastating impact of tobacco consumption and exposure to tobacco smoke'. ${ }^{51}$ The authors assert that the WHO FCTC has not only confronted the global tobacco epidemic, but has also generated a 'wealth of knowledge, experience, expertise, practice and jurisprudence' that will have 'profound significance far beyond tobacco and tobacco control for years to come'.52 In her chapter on noncommunicable diseases (NCDs), Garde adds that there is still no similar, legally binding global treaty on which national and regional policies on healthy diets and alcohol rest. ${ }^{53}$

Secondly, Article 21 of the WHO Constitution grants the WHA the authority to adopt regulations concerning five designated health-related

48 E.g. David Fidler, 'The Future of the World Health Organization, What Role for International Law?' (1998) 31(5) Vanderbilt Journal of Transnational Law 1079.

49 Aginam (n 16), Introduction.

50 Contribution by Seuba in this volume, section 4.3.

51 World Health Assembly, Resolution WHA56.1, WHO Framework Convention on Tobacco Control, 4th plenary meeting, Committee A, 1st report (21 May 2003). Contribution by Zhou and Liberman in this volume, section 1.

52 Contribution by Zhou and Liberman in this volume, section 7.

53 Contribution by Garde in this volume, section 2.2.2. 
matters, including sanitary and quarantine requirements for preventing the spread of disease and nomenclatures with respect to diseases, causes of death and public health practices. Interestingly, these regulations can produce binding obligations for all Member States that do not expressly 'opt out' or make reservations within a limited time frame. ${ }^{54}$ As such, they empower the WHA with extraordinary and far-reaching normative powers. ${ }^{55}$ To date, the WHA has adopted two sets of regulations: the 1967 Nomenclature Regulations and the authoritative 2005 International Health Regulations. ${ }^{56}$ The latter aim to "prevent, protect against, control and provide a public health response to the international spread of disease in ways that are commensurate with and restricted to public health risks ...' ${ }^{57}$ Negri, in her contribution on communicable diseases, gives a thorough assessment of this innovative regime.

Thirdly, the WHO Constitution provides for the possibility to adopt non-binding recommendations with respect to any matter within the competence of the WHO. ${ }^{58}$ As mentioned, these (soft law) recommendations can fill regulatory gaps where the international community is not ready to adopt a binding standard. An important example is the 1981 International Code of Marketing of Breast-Milk Substitutes, ${ }^{59}$ adopted in response to a rise in child mortality due to the promotion of breast-milk substitutes. According to the literature, the Code has had a moderately positive impact within the States that have implemented it. ${ }^{60}$ Another example concerns the 2011 Pandemic Influenza Preparedness Framework (PIP Framework), a non-binding instrument aimed at helping Member States, laboratories, industry, and civil society work together to better

54 Article 22 WHO Constitution. Michel Bélanger, Droit international de la santé (Economica 1983) 96; Gian Luca Burci and Claude-Henri Vignes, World Health Organization (Kluwer 2004) Chapter II, 132; as also quoted by Lawrence O. Gostin, Public Health Law: Power, Duty, Restraint (University of California Press 2008) 242.

55 Bélanger (n 54), 96.

56 Nomenclature Regulations 1957 and International Health Regulations 2005.

57 International Health Regulations, Article 2. Burci and Vignes (n 54).

58 Article 23 of the Constitution of the World Health Organization.

59 Sami Shubber, The WHO International Code of Marketing of Breastmilk Substitutes: History and Analysis (2nd edn, Pinter \& Martin Ltd 2011).

60 Ellen G. Piwoz and Sandra Huffman, 'The Impact of Marketing of Breast-Milk Substitutes on WHO-Recommended Breastfeeding Practices' (2015) 36(4) Food and Nutrition Bulletin 373. 
prepare the world for an influenza pandemic. ${ }^{61}$ A recent evaluation of the PIP framework suggests that since its inception there has been a marked increase in country level preparedness to influenza outbreaks. ${ }^{62}$

Furthermore, as discussed by both Garde and Ó Cathaoir and colleagues in their contributions, several recommendations have been adopted in response to the global rise in NCDs. Important strategies include the 2010 WHO Global Strategy to Reduce the Harmful Use of Alcohol, the 2004 WHO Global Strategy on Diet and Physical Activity and the 2013 WHO Global Action Plan for the Prevention and Control of NCDs 2013-2020.63 While these standards do not meet the FCTC's unprecedented success, they mark important steps in the further definition of a global response to NCDs. It is important to assess the value and impact of these instruments in light of their global setting, facilitating the involvement of many stakeholders. As Garde suggests in her contribution, there is no 'magic bullet' when it comes to the prevention and control of NCDs. ${ }^{64}$

\section{HUMAN RIGHTS LAW}

As suggested earlier, human rights law has a prominent normative role to play in global health law. Some evidence of this interaction is reflected by the Preamble to the FCTC, which makes explicit reference to the right to the highest attainable standard of health as recognized in Article 12 of the International Covenant on Economic, Social and Cultural Rights (ICESCR). ${ }^{65}$ As illustrated in this Handbook, the importance of human rights for public health and health law is increasingly emphasized in the literature. 66

Over the course of the past 70 years, an impressive body of international human rights law has emerged, encompassing many rights that have explicit or implicit relevance for the protection of health as well as

61 Pandemic Influenza Preparedness Framework (PIP), <http://www.who.int/ influenza/pip/en/>, accessed 2 February 2018.

62 Dalberg, External Evaluation of the Pandemic Influenza Preparedness Partnership Contribution - High Level Implementation Plan 2013-2016, <http:// who.int/about/evaluation/pip_evaluation_report.pdf>, accessed 2 February 2018.

63 See also Garde in this volume, section 2.2.2., supra note 43.

64 Garde, section 2.2.2.

65 Preamble to the Framework Convention on Tobacco Control 2003.

66 See in particular the contribution by Tarantola and Gruskin on HIV/AIDS, and by Ó Cathaoir, Hartlev and Brassart Olsen on obesity. 
for the protection of individuals in healthcare settings. The first expression of health as a right was included in the Preamble to the 1946 WHO Constitution: 'the enjoyment of the highest attainable standard of health is one of the fundamental rights of every human being without distinction of race, religion, political belief, economic or social condition' ${ }^{67}$ This authoritative definition set the stage for the recognition of a right to health in a wide range of human rights treaties that were adopted thereafter, including the 1966 ICESCR. ${ }^{68}$

In addition to the right to health, a broad catalogue of rights are important in the context of health, including the rights to life, privacy, and information, as well as rights to housing, education, and food. In the literature, there is increasing recognition of 'health and human rights' as a distinct branch of human rights law. ${ }^{69}$ An important impetus for the emergence of this field was the HIV/AIDS pandemic and reproductive and sexual health concerns. ${ }^{70}$ Tarantola and Gruskin illustrate in their contribution to this volume how HIV/AIDS has been instrumental in clarifying the ways that health and human rights connect. ${ }^{71}$

Regional human rights treaty bodies, in particular the European Court of Human Rights (ECtHR), have also played a crucial role in clarifying how civil and political rights, including rights to life, the prohibition of torture, and the right to privacy and family life, interact with the health field. ${ }^{72}$ According to Hendriks, the ECtHR has come out with 'farreaching judgments in the fields of health law and medicine, based on the assumption that healthcare represents an important value in society'. ${ }^{73} \mathrm{As}$ Hendriks explains, while the European Convention on Human Rights (ECHR) does not contain a right to health or healthcare, based on the Court's case law several (positive) obligations are imposed on contracting States relevant to health-related concerns. ${ }^{74}$ These obligations are based on several rights in the ECHR, including Articles 2 (life), 3 (prohibition of torture), 8 (privacy and family life), and 10 (freedom of expression and

\footnotetext{
67 Preamble to the Constitution of the World Health Organization 1946.

68 International Covenant on Economic, Social and Cultural Rights 1966.

69 John Harrington and Maria Stuttaford, Global Health and Human Rights - Legal and Philosophical Perspectives (Routledge 2010), Michael Grodin et al, Health and Human Rights in a Changing World (Routledge 2013), Thérèse Murphy, Health and Human Rights (Hart Publishing 2013), Toebes et al (n 40).

70 Toebes et al (n 40) 7.

71 Chapter by Tarantola and Gruskin, section 3.

72 A.C. Hendriks, 'The Council of Europe and Health and Human Rights', in Toebes et al (n 40) 21.

73 Hendriks (n 72) 27.

74 Hendriks (n 72) 43 and 50.
} 
access to information). Health concerns that the Court has touched on include: a denial of access to medical care and dysfunctional health systems; protection of vulnerable persons in healthcare settings and involuntary confinement; access to personal data; abortion; euthanasia; forced sterilization; and environmental health matters. ${ }^{75}$

A key question for this Research Handbook concerns the role and position of the 'right to health' and of the field of 'health and human rights' in global health law. Potentially, the right to health may feature as a core, unifying standard in the field. However Gostin, in his 2014 book Global Health Law, sees many flaws in the right to health as expressed in Article 12 of the ICESCR, including the perceived failure to identify obligations with sufficient detail. ${ }^{76}$ Despite his qualms about the right to health, he adopts it as one of the pillars of global health law, asserting that it is the only available quasi-universally applicable international regime designed to safeguard public health. ${ }^{77}$ Tobin and Murphy, in their contributions to this volume, pay considerable attention to Gostin's approach and to the role of human rights in global health more generally. Tobin, in his chapter on the right to health, whilst recognizing Gostin's concern, makes an attempt to explore some of the ways in which the right to health is relevant to the field of global health law. He discusses the normative and philosophical foundations of the right to health in an attempt to rebut the critique that the right to health is open-ended and vague. Yet, he also recognizes and discusses controversial dimensions in the right to health, including the tension between the protection of public and individual health, and the question whether the right to health also encompasses the social determinants to health. ${ }^{78}$

Murphy, in her contribution about health and human rights, expresses unease about global health law, in particular in the way it is defined by Gostin. She sees global health law more as a 'collection of problems than a coherent undertaking, and unlikely ever to be a field of law in any

75 Examples include: dysfunctional health systems: e.g. ECtHR Asiye Genc v. Turkey, 27 January 2015, No. 24109/07 and Vasileva v. Bulgaria, 17 March 2016, No. 23796/10; involuntary confinement: ECtHR 16 June 2005, Storck v. Germany, No. 61603/00 ECtHR 13 January 2009; access to personal data: ECtHR 4 May 2000, Powell v. UK, No. 45305/99; abortion: ECtHR 5 September 2002, Boso v. Italy, No. 50490/99; euthanasia: ECtHR 29 April 2002, Pretty v. $U K$, No. 2346/02; and environmental health protection: ECtHR 9 June 2005, Fadeyeva v. Russia, No. 55723/00. For a comprehensive overview (updated until 2012) see Hendriks (n 72).

76 Gostin (n 1) 20.

77 Gostin (n 1) xv.

78 Tobin's chapter, in particular section 3.3 and 3.4. 
positive, productive sense of that term' ${ }^{79}$ She argues that it 'could mutate how we see human rights law', and that it could strip human health and human rights 'of mass and dimension' ${ }^{80}$ In particular, she is concerned about the way in which global health law expresses economic, social and cultural rights, and the right to health in particular. Murphy is concerned that in the current interpretation of global health law, economic, social and cultural rights are seen as imprecise and unenforceable. Furthermore, when it comes to the right to health, her concern is that it is seen as a very broad right with a public rather than individual connotation. ${ }^{81}$

Without repeating these positions, for the purposes of this introductory chapter four foundational observations can be made in relation to the role of human rights in global health law. Firstly, it is important to stress that human rights law, or the right to health as such, is not synonymous with global health law. Human rights law represents a narrower legal field with its own specific tools and characteristics. Global health law, if it is a field at all, is closely intertwined with human rights law, but clearly has a far wider scope than the relevant health-related standards identified under international human rights law.

Having said this, and by way of a second observation, it is clear that human rights, and the right to health in particular, play an important foundational role in global heath law. Human rights standards place the protection of the dignity, health, and well-being of the individual at the centre of the debate. They defend individual interests against the powerful needs and demands of international trade and commerce, excessive patent protection, aggressive marketing of unhealthy products, and even the devastating effects of warfare.

Thirdly, and related to the second observation, the right to health should not be conceived as a repository for everything that remotely relates to health. ${ }^{82} \mathrm{~A}$ recognition of the right to health as a key right in global health law does not mean that other human rights, or ethical principles, are not important in this field. As Tobin asserts, 'caution must be exercised when inflating the scope of the right to health to ensure that it does not colonise the discrete normative territory occupied by other economic and social rights like housing, food, nutrition and employment' ${ }^{83}$ In addition to economic, social and cultural rights as mentioned

\footnotetext{
79 Chapter by Murphy, section 3.

80 Murphy, section 1.

81 Murphy, section 4.1.1. See also Mason Meier (n 44).

82 B. Toebes, The Right to Health as a Human Right in International Law (Intersentia 1999) 259, and Tobin in his contribution to this work, section 3.2.

83 Chapter by Tobin, section 3.4.
} 
by Tobin, ethical principles, patients' rights and civil and political rights are also important in global health law. When it comes to civil and political rights, of key importance is the sophisticated case law of the ECtHR reflecting the Court's increasing engagement with the protection of the health and dignity of patients and other right holders, which merits further scrutiny, also by jurisdictions beyond the borders of Europe. ${ }^{84}$

Fourthly and finally, in order to ensure that the human rights framework is not discharged for being vague and open-ended, it is important to rely on the specific concepts and tools developed under human rights law. This requires careful scrutiny of the CESCR's General Comment 14 and the CRC's General Comment 15 on the right to health, and the CESCR's General Comment 22 on Reproductive and Sexual Health, as authoritative explanations of the right to health. ${ }^{85}$ Although they are soft law, these documents reflect a number of key concepts and tools explaining the implications of the right to health, including the identification of the 'AAAQ', the identification of States' legal obligations to respect, protect and fulfil the right to health, and the recognition of minimum core obligations. ${ }^{86}$ Recognition must also be given to the Concluding Observations from the various human rights treaty bodies, as well as the health-related case law from regional and domestic courts. Even though human rights standards and tools by their very nature are open-ended, they have a remarkable level of sophistication despite their global scope. Global health should reinforce these standards rather than undermine them.

\section{INTERCONNECTED FIELDS OF PUBLIC INTERNATIONAL LAW}

To create a degree of coherence in global health law, it is important to look at other international legal disciplines that can feed into the field of international health law, in particular international trade law, intellectual property rights, international investment law, international environmental law, and international humanitarian law. The chapters by McGrady,

\footnotetext{
84 Hendriks (n 72).

85 Committee on Economic, Social and Cultural Rights, General Comment 14 on the Right to the Highest Attainable Standard of Health 2000, UN Doc. E/C12/2000/4.

86 Committee on Economic, Social and Cultural Rights, General Comment 3, The Nature of States' Parties Obligations 1990, UN Doc. E/1991/23 and General Comment 14 (n 85).
} 
Abbott, Giorgetti, Mbengue and Waltman, and Bellal cover these fields in their respective contributions to this Research Handbook.

McGrady deals with the interaction between government action to protect health (called 'the right to regulate') and international trade agreements. The author explains that there is an inherent tension between the two, given that trade agreements limit the power of States to intervene in markets, including through regulation. ${ }^{87}$ This may be an area of concern as several empirical studies have established a link between trade liberalization and increasing demand for tobacco products and processed food in low and middle income countries. ${ }^{88}$ Nonetheless, and despite these concerns, McGrady, after an assessment of the various legal dimensions in international trade law, concludes that there is a fairly predictable balance between rights and obligations, generally protecting bona fide health measures. ${ }^{89}$ This seems to satisfy Garde's aspiration voiced in her chapter, that global health law and international trade law are complementary and mutually supportive with a view to ensuring the best possible balance between competing interests. ${ }^{90}$

Abbott, in his chapter on intellectual property (IP), asserts that IP plays a significant yet controversial role in the health sector. For example, allowing patent owners to charge high prices for HIV drugs had a devastating effect on millions of patients who could not afford these drugs. Abbott suggests that patents and regulatory exclusivity should be regulated in the interests of affordability and access. In addition, according to the author, a reorganization of finance, production and distribution mechanisms is required, as well as a rethinking of the way in which research and development efforts are encouraged. Yet, similar to McGrady, Abbott is not necessarily pessimistic about balancing the right to regulate and the protection of IP rights within the framework of the WTO dispute settlement system. Abbott explains that, thus far, the WTO dispute settlement system has been 'empathetic to the concerns of developing countries in terms of implementation and enforcement of IP when there may be an impact on public health'. ${ }^{91}$ In addition, he lauds the WHO for providing 'continuing guidance to its member countries regarding interpretation and implementation of IP law'. ${ }^{92}$

\footnotetext{
87 Contribution by McGrady, section 1.

88 See Garde in this volume, section 3.

89 McGrady, section 6.

90 Garde, section 3.2.

91 Contribution by Abbott, section 3.1.

92 Abbott, section 3.1.
} 
Giorgetti deals with the interaction between public health and international investment law. Contrary to international trade law and IP law, international investment law lacks an overarching multilateral legal framework and is regulated largely through bilateral and regional treaties. The general formulation of investors' rights in these instruments raised concerns that a State's regulatory power in the context of public health, environmental health, and consumer health might be limited. A new generation of investment treaties-which specifically protect public health — and a series of recent investment arbitration cases, analysed by Giorgetti in her chapter, provide some confidence that States continue to enjoy extensive regulatory powers in matters related to public health. Among others, the author discusses the widely cited 2016 Philip Morris v. Uruguay case, in which the Tribunal decided in favour of Uruguay and held that by adopting public health protection measures Uruguay had properly used its regulatory power and, therefore, that these measures did not amount to indirect expropriation. ${ }^{93}$

The subsequent two chapters deal with international environmental law and international humanitarian law. These two chapters hold value for two interconnected reasons. Firstly, and as was discussed above, the chapters explain how both fields set important examples for global health law as fields with similar aims, objectives, and principles. Scholars interested in global health law can learn from these fields, for example when it comes to the development of general principles. Secondly, the chapters illustrate how these two fields have importance and relevance to global health law in the way they explicitly protect health.

Environmental degradation is increasingly becoming responsible for poor health in many parts of the world, ${ }^{94}$ and is therefore an important topic of concern for a volume on global health law. Mbengue and Waltman explain that the protection of human health is at the core of international environmental law. Several principles and a wide range of environmental treaties recognize the importance of the protection of human health. The authors stress that given the vital role that the environment plays for health, global health law and international environmental law should be addressed in the same legal framework. In this regard, they see many opportunities for addressing health concerns in the context of the international environmental law regime.

93 International Centre for Settlement of Investment Disputes (ICSID), Philip Morris v. Uruguay, Case No. ARB/10/7 (2016), see Giorgetti's chapter, section 3.1.3.

94 Mbengue and Waltman, section 2. 
Similarly, international humanitarian law is an area of vital concern for the protection of health. Bellal, in her chapter on the protection of health in international humanitarian law, explains that the effects of armed conflict go far beyond causing direct combat-related deaths, and also include long-term physical and mental disabilities, a breakdown of health systems and overall infrastructure. ${ }^{95}$ Bellal explains that the protection of human health has been at the core of international humanitarian law since its inception, including the protection of the wounded and sick, but also that of hospitals, medical units and personnel. While the level of standard-setting is satisfactory, the implementation of the standards is falling short, which is reflected in frequent attacks on hospitals and medical personnel. The author emphasizes the need to involve non-State armed groups in a better implementation of the international humanitarian law standards, through encouragement rather than stigmatization.

\section{KEY HEALTH-RELATED THEMES}

Part 3 of this Research Handbook addresses key themes in global health law, i.e. communicable diseases, including specifically HIV/AIDS, NCDs, tobacco control, and obesity, as well as harmonization and standardization in global health. Several contributions discuss the interaction between the WHO standards and human rights, and express the need to use human rights standards to reinforce the existing WHO regimes. ${ }^{96}$

Communicable diseases have been at the core of the emerging regime of standard-setting in the field of public health since the late nineteenth century. Negri, in her contribution on communicable diseases, explains how the WHO and its predecessor have gradually adopted and amended health regulations offering a legal regime of surveillance and control of infectious diseases. ${ }^{97}$ The 2005 revised International Health Regulations go far beyond the previous health regulations by taking an 'all hazards approach', applying 'to any illness or medical condition, irrespective of origin or source, that presents or could present significant harm to humans' ${ }^{98}$ Yet they also reflect shortcomings, in particular when it comes to their effective implementation, lack of enforceable sanctions,

\footnotetext{
95 Bellal, Introduction.

96 Contributions by Negri; Tarantola and Gruskin; Zhou and Liberman; Garde; and Ó Cathaoir et al.

97 Chapter by Negri, section 2.

98 Article 1 of the IHR (2005); Negri in her contribution, section 3.
} 
and the lack of systematic monitoring of human rights violations committed in the implementation of the Regulations. ${ }^{99}$

The chapter by Tarantola and Gruskin on the evolution of the HIV and human rights interface has in essence two purposes. Firstly, it serves to explain how the HIV/AIDS movement was instrumental to the development of health and human rights as a distinct and multidisciplinary field of human rights law. Among other developments, the chapter discusses the new global strategy to end the AIDS epidemic by 2030 as a promising development. The authors anticipate that based on the existing 30 years of experience in HIV and human rights, this new framework could become a success. ${ }^{100}$ Secondly, their chapter illustrates how human rights can continue to serve not only as the foundation of the response to HIV/AIDS, but also to other major health concerns of our time, including tuberculosis and malaria, sexual and reproductive health, and NCDs.

While communicable diseases have represented a major public health threat since the dawn of humanity, ${ }^{101}$ attention also needs to be paid to NCDs as the largest public health threat of our times. The WHO estimates that by 2030, NCDs will be the leading cause of death in every region in the world. ${ }^{102}$ This pandemic will also come with considerable cost: according to the World Economic Forum, NCDs will cost more than $\$ 30$ trillion over the next 20 years, representing 48 per cent of global GDP. ${ }^{103}$ Chronic diseases are also called lifestyle diseases as they are generally linked to four shared risk factors that enhance the incidence of these diseases: tobacco use, unhealthy diet, physical inactivity and harmful use of alcohol. It is therefore of the utmost importance to address the role that international law may play in modifying these risk factors in this work.

So far, tobacco remains the only risk factor that is successfully regulated through a treaty. The 2003 FCTC has led to a tightening of many domestic tobacco laws and to several domestic court cases addressing the harmful effects of tobacco. The chapter on tobacco control by Zhou and Liberman explains the evolution and successes of the FCTC

\footnotetext{
99 Negri, section 6.

100 Contribution by Tarantola and Gruskin, section 6.

101 Negri's chapter, referring to Mehdi et al, supra note 3 in Negri, section 1.

102 World Health Organization, Global Status Report on Noncommunicable Diseases, <http://www.who.int/nmh/publications/ncd-status-report-2014/en/> (2014) accessed 2 February 2018.

103 Harvard University/World Economic Forum (September 2011), The Global Economic Burden of Non-Communicable Diseases, <http://apps.who.int/ medicinedocs/documents/s18806en/s18806en.pdf> accessed 2 February 2018.
} 
framework. The authors assert that the fact that tobacco is now regulated through a binding treaty has been critical to its influence at global, regional and domestic levels.

Garde, in her chapter on NCDs, pays attention to the relationship between law and NCD prevention, looking more specifically at how global health law has developed in this field and why it remains unevenly implemented at national and regional levels. For unhealthy diets and alcohol, the WHO has developed a set of global strategies, action plans, recommendations and other policy documents. However, their implementation lacks the strong political will and leadership which we have witnessed in relation to tobacco control.

Ó Cathaoir, Hartlev and Brassart Olsen focus on obesity in the context of global health law. Their chapter illustrates that obesity currently affects all regions of the world with 39 per cent of the global adult population being overweight and 11 per cent obese. ${ }^{104}$ Despite the need to take transnational action, global norms currently play a limited role in obesity prevention. The authors observe that there is a lack of political will, absence of political mobilization, misperceptions about the causes of obesity, and confusion on the role of laws and policy to prevent obesity. ${ }^{105}$ While the authors see human rights law as an important complementary field, they argue that the approaches of the CRC Committee and CESCR should be strengthened and that there should be more cohesion between human rights and international public health to adequately address this topic of huge international public health concern.

Last but not least, Seuba deals with the international harmonization of pharmaceutical standards. The chapter illustrates how the pharmaceutical field reflects a shift to hybrid public-private forms of governance and law making. Specific attention is paid to the ICH. Seuba explains how a wide range of activities are conducted within the framework of the ICH, with the goal of enhancing the safety, quality, and efficacy of medicines. The author concludes that the ICH has been highly efficient in most of its objectives, and that the quality of the standards is beyond doubt. However, these efforts are mainly laid down in soft law instruments, and the pharmaceutical industry is actively engaged in their adoption. The author suggests that either the WHO should take leadership-which is very difficult, as it does not have the necessary means and/or people-

104 World Health Organization, Overweight and obesity, <http://www.who. int/gho/ncd/risk_factors/overweight_text/en/> accessed 2 February 2018, in Ó Cathaoir et al, section 2.

105 Contribution by Ó Cathaoir et al, section 8. 
or the ICH membership should become open to all States in equal conditions.

\section{GLOBAL HEALTH LAW: A DIAMOND IN THE ROUGH}

This Introduction has shown that global health law does not constitute a coherent body of international law. Rather, what we see is a disjointed field with unclear boundaries consisting of hard and soft law standards guaranteed at both international and regional levels. As such, the question arises as to how we should perceive global health law: is it a mere aspiration, is it a field in the making, or can we confidently speak of an existing branch of international law? Let us be both realistic and optimistic. Realistic in the sense that global health law is not a wellestablished branch of international law with a clear set of overarching principles and a coherent set of international legal standards. Yet, optimistic given that there is a clear movement or process toward global health law within international law, governance and legal scholarship.

To prevent this emerging and fragile field from becoming an empty shell or a mere slogan, we should very carefully analyse its legal characteristics and consistently scrutinize how the various dimensions of global health law interact. Scholarship in the legal and governance fields is thus of the utmost importance. We hope this Research Handbook forms a meaningful contribution to this important objective. 